\title{
Determining the Views and Adequacy of the Preschool Teachers Related to Science Activities
}

\author{
Nilüfer Okur Akçay \\ Faculty of Education, Agri Ibrahim Cecen University, Turkey
}

Copyright $(2016$ by authors, all rights reserved. Authors agree that this article remains permanently open access under the terms of the Creative Commons Attribution License 4.0 International License

\begin{abstract}
In this study, it is aimed to determine the views and adequacy of the preschool teachers related to science activities. The study is based on descriptive survey model. The sample of the study consists of 47 preschool teachers working in Ağrı city center. Personal information form, semi-structured interview form to determine the views of the teachers related to science education and "Teacher Proficiency Scale for Preschool Activities in Science (TPSPAS)" developed by Özbey [21] were used in the study as data collection tools. Frequency and percentage table in the analysis of the data obtained from the personal information form, ANOVA in the analysis of the data obtained from TPSPAS and content analysis in the analysis of the data obtained from the semi-structured interview form were used. As a result of the study, it was determined that the preschool teachers think that science activities are important for the children, however, they feel inadequate themselves about science topics. Moreover, it was determined with this study that there are differences between the adequacy scores of the preschool teachers related to science activities and the variables of age, seniority and the school they graduated in terms of the different dimensions of the scale.
\end{abstract}

Keywords Science Activities, Views, Adequacy, Preschool

\section{Introduction}

The process of pre-school education took place in the first years of life are crucial for the development and education of the child. Preschool education is actually the process which includes the period from birth to primary school and it aims to support the developments of the children at this age (Macaroğlu [19]). The children in the preschool period in which their curiosity towards the world they live in starts to increase and their desire to get new information is quite intensive get new information by making investigation and they try to relate the cause and effect relationship by underlying the configuration of each new information with the information they've got (Balat and Önkol [6]). When an individual is mostly active and open to learning is the first 3-6 years of his/her life. In this period, the individual has quite much energy and his/her perception level about what happens around is at its most (Küçükturan [18]). Therefore, science education should be given to individuals in the preschool period in a good way. As a subject of each event in the nature of science, science is an important part of life. Thanks to science education, the children find the opportunity to experience and live and learn and learn more, to develop problem solving skills, to know the features of the equipments they can encounter in their daily life (Dikmen [9]). Science education in preschool, which is a course required students to help them understand what they see around them.

According to the results of several studies conducted on preschool education (Ginsburg and Golbeck [11]; Patrick et al. [22]; Early et al. [10]), it is said that the children have the tendency to observe and think about nature and this tendency is gained during preschool period, also children's desire to learn science is higher than their desire to learn reading and writing, mathematics, art and social learning fields. According to Kalley and Psillos [17], basic science concepts start to be formed in the early childhood period which cover the first six years of life, in which physical, mental, emotional and social developments of the children is fast. So, the first planned and programmed education towards science takes place according to the children's interests and needs in preschool institutions. Thus, to support the children's developments in this way, the teachers should implement the science teaching by giving that the children the opportunity that they can observe, research, comprehend, test with active participation, bring forward their ideas, use their creativity and the teachers should consider the development levels, interests of the children, the opportunities of the environment and they should choose appropriate methods and techniques. Therefore, the children should be given the opportunity to observe, investigate, comprehend, make experience with active participation, put forward ideas, and use their creativity to support their development in this direction, and teachers should implement the science teaching with appropriate methods and techniques considering 
development levels and interests of the children and environmental opportunities (Aktaş [2]; Bal [5] ; Yasar [27]).

While teachers should give due importance to science activities and spare time to these activities, science is generally neglected in early childhood classrooms (Akçay [1]). The reason of this neglect is that the preschool teachers get the idea that science is full of extremely abstract and theoretical information and it is not possible for the children to comprehend this information, and so they do not spare enough time to science activities in their lessons. For these reasons, mostly teachers are unable to spend enough time to science lessons. According to Cho et al. [7], one of the most important reasons why the preschool teachers spare less time to science activities is that the teachers do not have adequate content knowledge about basic scientific concepts. In similar studies, it was determined that the adequacy beliefs of the preschool teachers are low, scientific content knowledge of them is limited, and they do not trust themselves about science (Pell and Jarvis [23]; Saçkes et al. [25]). Hence, the preschool teachers refrain from including science in their classes and keep the science activities at a minimum level. As a result of the study done by Saçkes et al. [24], it was found that most of the preschool teachers fulfill science teaching up to 60 minutes at most once or twice a week. It is so obvious that the teachers who show time limitation and lack of enough science materials as a reason to spare less time science teaching (Early et al. [10]; Greenfield et al. [12]; Saçkes [26]) ignore their lack of knowledge on science teaching.

In recent years in the fast development of the countries has increased the importance of science even more. In this direction, to move forward of Turkey in the scientific field there is a need for brain questioning, researchers, solutions to the problems which faced can bring suggestions. So, it is given importance to science in the new curriculum prepared in Turkey, especially in laying the foundations of science is intended to provide preschool education programs. Science education is of great importance especially in young age in imparting such properties. For this purpose, consideration should be given to science education in preschool. Therefore performance in this study aims to determine the preschool teachers' views and adequacy related with the science activities.

For this purpose, it has searched for answers to the following questions:

1. Preschool teachers what to consider before using science activities in the classroom?

2. Preschool teachers benefit from activities that teach children what science subjects?

3. Pre-school teachers benefit from applying the science activities which teaching methods and techniques?

4. What are the materials pre-school teachers use to do science activities?

5. According to the pre-school teachers should be given to pre-school science activities study?
6. What are the problems that preschool teachers encountered in implementing science activities?

7. Is preschool teachers adequacy related with the science activities being different from age variable?

8. Is preschool teachers adequacy related with the science activities being different from seniority variable?

9. Is preschool teachers adequacy related with the science activities be different from educational status variable?

\section{Method}

In this study mixed methods were used. Mixed methods research is a methodology for conducting research that involves collecting, analyzing, and integrating (or mixing) quantitative and qualitative research (and data) in a single study or a longitudinal program of inquiry. (McMillan and Schumacher [20]).

\subsection{Working Group}

The sample of this study consists of 47 preschool teachers working in Ağrı city center in 2014-2015 fall semesters. The Table 1 indicates the frequency and percentage values of the data obtained from the personal information form used in the study.

Table 1. Frequency and percentages related to the data obtained from personal information form

\begin{tabular}{|c|c|c|c|}
\hline Variables & & f & \% \\
\hline \multirow{4}{*}{ Age distributions } & $20-25$ & 25 & 53 \\
\cline { 2 - 4 } & $26-30$ & 14 & 30 \\
\cline { 2 - 4 } & $31-35$ & 6 & 13 \\
\hline \multirow{4}{*}{ Year of seniority } & $36-40$ & 2 & 4 \\
\cline { 2 - 4 } & $0-5$ & 38 & 81 \\
\cline { 2 - 4 } & $6-10$ & 5 & 11 \\
\cline { 2 - 4 } & $11-15$ & 2 & 4 \\
\hline \multirow{3}{*}{$\begin{array}{c}\text { Educational } \\
\text { Status }\end{array}$} & $16+$ & 7 & 4 \\
\cline { 2 - 4 } & Open University & 5 & 11 \\
\cline { 2 - 4 } & Associate Degree & 35 & 74 \\
\hline \multirow{4}{*}{ Bachelor's Degree } & 47 & 100 \\
\hline
\end{tabular}

On analyzing the Table 1 , it is seen that $53 \%$ of the preschool teachers are $20-25$ years old, $30 \%$ of them are 26-30 years old, $13 \%$ of them are 31-35 years old, $4 \%$ of them are $46-40$ years old; $81 \%$ of the teacher' years of seniority is between $0-5$ years, $11 \%$ of them is between $6-10$ years, $4 \%$ of them is between $11-15$ years, $2 \%$ of them is between $16-20$ years and $2 \%$ of them is 20 years and above; $74 \%$ of the teachers have Bachelor's Degree, $15 \%$ of them have Open University Degree and $11 \%$ of them have Associate Degree. 


\subsection{Data Collecting Tool}

Personal information form, semi-structured interview form prepared by the researcher and consisting of 6 questions ("What things do you consider before implementing science activities in your class?", "What activities do you make use of when teaching science topics to the children?", "Which education methods and techniques do you make use of the most when implementing science activities?", "which science topics do you base your planning the science activities?", "Why should the science activities be implemented in preschool period?", "Are there any problems that you encounter while implementing science activities? If so, what are they?") and "Teacher Proficiency Scale for Preschool Activities in Science (TPSPAS)" developed by Özbey [21] were used in the study. TPSPAS consists of four sub-dimensions as the materials and methods the teachers use, knowledge levels of the teachers related to implementation, general knowledge level related to science activities and the behaviors presented during the implementation of the science activities. The scale is a 5-likert scale consisting of 29 items (17 of them are positive and 12 of them are negative). Özbey [21] found the Cronbach-alpha reliability coefficient as 0.82 in his study. The Cronbach-alpha reliability coefficient of TPSPAS was calculated for this study and it was found as 0.78 . The table below indicates the items related to the sub-dimensions of TPSPAS.

Table 2. The question samples of the sub-dimensions of TPSPAS

\begin{tabular}{|c|l|}
\hline $\begin{array}{c}\text { The sub-dimensions } \\
\text { of TPSPAS }\end{array}$ & \multicolumn{1}{c|}{ Items } \\
\hline $\begin{array}{c}\text { The materials and } \\
\text { methods the } \\
\text { teachers use }\end{array}$ & $\begin{array}{l}\text { 1. I am attentive to find different materials such } \\
\text { as books, magazines, newspapers, } \\
\text { documentaries for science activities. } \\
\text { 2. I frequently organize study trips within } \\
\text { science activities. }\end{array}$ \\
\hline $\begin{array}{c}\text { The knowledge } \\
\text { levels of the } \\
\text { teachers related to } \\
\text { implementation } \\
\text { in preschool science activities; the children } \\
\text { choose the appropriate solution. } \\
\text { 2. I explain to the children what happens as a } \\
\text { result of the experiments done in preschool } \\
\text { science activities. }\end{array}$ \\
\hline $\begin{array}{c}\text { The general } \\
\text { knowledge level of } \\
\text { the teachers related } \\
\text { to science activities }\end{array}$ & $\begin{array}{l}\text { 1. The teacher should be in a position in which } \\
\text { s/he is the one researching and learning with } \\
\text { the children during the science activities. } \\
\text { 2. Preschool science activities should be } \\
\text { planned in order to develop problem solving } \\
\text { skills, creative thinking and observation skills } \\
\text { of the children. }\end{array}$ \\
\hline $\begin{array}{c}\text { The behaviors the } \\
\text { teachers present } \\
\text { during the }\end{array}$ & $\begin{array}{l}\text { 1. I implement science activities by integrating } \\
\text { them with games, music, drama, Turkish } \\
\text { language activities and preparation for reading } \\
\text { and writing activities. } \\
\text { 2. I tell the children what to do in each phase of } \\
\text { an experimentation of }\end{array}$ \\
\hline
\end{tabular}

\subsection{Data Analysis}

Frequency and percentage table in the analysis of the data obtained from the personal information form, ANAVO in the analysis of the data obtained from TPSPAS and content analysis in the analysis of the results obtained from the semi-structured interview form were used.

\section{Findings}

Content analysis was done for the data obtained from the semi-structured interview form consisting of 6 questions and prepared by the researcher to determine the views of the preschool teachers related to science education and the results are indicated in Table 3, 4, 5, 6, 7 and 8 .

Table 3. The frequency and percentage of the answers to the question "what things do you consider before implementing science activities in your class?"

\begin{tabular}{|c|c|c|}
\hline Views & f & \% \\
\hline I consider the interests of the children & 13 & 28 \\
Without any criterion, I implement the activities & & \\
that I think at that moment & 23 & 49 \\
I consider the syllabus & 11 & 23 \\
Total & 47 & 100 \\
\hline
\end{tabular}

As it can be seen in Table 3, $28 \%$ of the preschool teachers plans the science activities according to the interest and desires, $49 \%$ of them plans the science activities depending on their instant thoughts without any criterion and $23 \%$ of them plan the activities considering the syllabus.

Table 4. The frequency and percentage of the answers to the question "what activities do you make use of when teaching science topics to the children?"

\begin{tabular}{|c|c|c|}
\hline Views & f & \% \\
\hline Turkish language activity & 5 & 11 \\
Art activities & 12 & 26 \\
Reading-writing preparation activities & 9 & 19 \\
Free time activities & 11 & 23 \\
Game activities & 7 & 15 \\
Music activity & 3 & 6 \\
Total & 47 & 100 \\
\hline
\end{tabular}

It can be seen in Table 4 that $26 \%$ of the preschool teachers make use of art activities, $23 \%$ of them make use of free time activities, $19 \%$ of them make use of reading-writing preparation activities, $15 \%$ of them make use of game activities, $11 \%$ of them make use of Turkish language activities, $6 \%$ of them make use of music activities while teaching science topics.

Table 5. The frequency and percentage of the answers to the question "which education methods and techniques do you make use of the most when implementing science activities?"

\begin{tabular}{|c|c|c|}
\hline Views & f & \% \\
\hline Collaborative learning & 3 & 6 \\
Demonstration & 6 & 13 \\
Experiment & 9 & 19 \\
Observation trip & 5 & 11 \\
Problem solving & 4 & 9 \\
Concept map & 3 & 6 \\
Expression & 10 & 21 \\
Case study & 2 & 4 \\
Total & 47 & 100 \\
\hline
\end{tabular}


As it can be seen in Table 5, $21 \%$ of the preschool teachers use expression method, $19 \%$ of them use experiments, $13 \%$ of them use demonstration, $11 \%$ of them use observation trip, $9 \%$ of them use problem solving, $6 \%$ of them use concept map and collaborative learning, $4 \%$ of them use case study methods and techniques while implementing science activities.

On analyzing Table 6 , it is seen that $45 \%$ of the teachers include seasons, $36 \%$ of them include living and inanimate, $36 \%$ of them include our organs, $32 \%$ of them include our world, 28 of them include plants and animals, $23 \%$ of them include colors, $17 \%$ of them include sound, $13 \%$ of them include light and $11 \%$ of them include magnetism in their science activities.

Table 6. The frequency and percentage of the answers to the question "which science topics do you base your planning the science activities?"

\begin{tabular}{|c|c|c|}
\hline Views & f & \% \\
\hline Seasons & 21 & 45 \\
Living and inanimate & 17 & 36 \\
Our organs & 17 & 36 \\
Our world & 15 & 32 \\
Plants and animals & 13 & 28 \\
Colors & 11 & 23 \\
Sound & 8 & 17 \\
Light & 6 & 13 \\
Magnetism & 5 & 11 \\
\hline
\end{tabular}

*Each teacher responded more than one.
As it is seen in Table 7, the percentage of the teacher and their reasons why science activities should be implemented in preschool as following: $30 \%$ of them think that because the children are in the period of researching and exploring, $15 \%$ of them think the children know their environment, $15 \%$ of them think science activities improve the thinking capacity of the children, $13 \%$ of them think they provide the children to know the nature by using their sense of wonder and curiosity, $13 \%$ of them think that the children develop a positive perspective towards the nature and other living things, $9 \%$ of them think they develop the children's problem solving skills, $6 \%$ of them think that they develop the children's creativity.

It is seen in Table 8 that the $30 \%$ of the preschool teachers have difficulty in responding to some of the children's questions, $28 \%$ of them have difficulty in explaining the subject in full detail, $15 \%$ of them have difficulty in presenting the abstract subjects, $11 \%$ of them have difficulty that the children get too excited and cannot gather their attention, $9 \%$ of them have difficulty in being unable to find experiments which are understandable and appropriate to the levels of the children, $9 \%$ of them have the difficulty that the children stand up and distract the attention of their friends.

Table 7. The frequency and percentage of the answers to the question "Why should the science activities be implemented in preschool period?"

\begin{tabular}{|c|c|c|}
\hline Views & f & $\%$ \\
\hline As the children are in the period of researching and exploring & 14 & 30 \\
\hline To know their environment & 7 & 15 \\
\hline To increase their thinking capacity & 7 & 15 \\
\hline To provide the children to know the nature by using their sense of wonder and curiosity & 6 & 13 \\
\hline It provides the children to develop a positive perspective towards the nature and other living things & 6 & 13 \\
\hline To develop their problem solving skills & 4 & 9 \\
\hline It improves the creativity of the children & 3 & 6 \\
\hline Total & 47 & 100 \\
\hline
\end{tabular}

Table 8. The frequency and percentage of the answers to the question "Are there any problems you encounter while implementing science activities? If so, what are they?"

\begin{tabular}{|c|c|c|}
\hline Views & f & $\%$ \\
\hline Having difficulty in responding to some of the children's questions & 14 & 30 \\
\hline Being unable to explain the subject in full details & 13 & 28 \\
\hline The difficulty in presenting the abstract subjects & 7 & 15 \\
\hline The children get too excited and they have difficulty in gathering attention & 5 & 11 \\
\hline Being unable to find experiments understandable and appropriate to the levels of the children & 4 & 9 \\
\hline The children stand up and distract their friends' attention & 4 & 9 \\
\hline Total & 47 & 100 \\
\hline
\end{tabular}


ANOVA test was done in order to determine the differences between the average scores of the preschool teachers from the sub-dimension of TPSPAS in terms of age. The results of the test are indicated in Table 9. When Table 9 analyzed, it is seen that there is a significant difference between the average scores of the preschool teachers from each sub-dimension of TPSPAS and their ages $(p<0.05)$. Tukey test, one of the multi-comparison tests, was used to determine that this difference is in favor of which age group. As a result of Tukey test, it was determined that for the materials and methods the teachers use sub-dimension, there is no significant difference between the adequacy scores of the teachers 26-30 years old and 20-25 and 31-35 years old, however the average scores of them are higher than other groups, there is a difference between the teachers at the age of 36-40 and this difference is not in favor of the teachers at the age of 36-40; for the knowledge levels of the teachers related to implementation sub-dimension, there is no significant difference between the average scores of the teachers at the age of $20-25,26-30$ and $31-35$, there is a difference in the adequacy of the teachers at the age of 36-40 and this difference is not in favor of the teachers at the age of 36-40; for general knowledge level of the teachers related to science activities, there is no significant difference between the average scores of the teachers at the age of 26-60 and the teachers at the age of 20-25, however, there is significant difference between the average scores of the teachers at the age of 31-35 and 36-40 and this difference is in favor of the teachers at the age of 20-25 and 26-30; for behaviors presented during the implementation of the activities sub-dimension, there is no significant difference between the adequacy scores of the teachers at the age of 20-25 and the teachers at the age of 26-30, however, there is significant difference between the teachers at the age of 31-35 and 36-40 and this difference is in favor of the teachers at the age of 20-25 and 36-40. ANOVA test was done in order to determine the difference in terms of years of seniority between the average values of the scores of the preschool teachers from the sub-dimension of TPSPAS. The results of the test are indicated in Table 10.

Table 9. The ANOVA results of the preschool teachers in terms of age variable

\begin{tabular}{|c|c|c|c|c|c|c|}
\hline Sub-dimensions & & SS & df & MS & F & P \\
\hline \multirow{4}{*}{$\begin{array}{c}\text { The materials and methods the } \\
\text { teachers use }\end{array}$} & Between groups & .919 & 3 & .306 & 3.281 & .030 \\
\cline { 2 - 7 } & Within groups & 4.015 & 43 & .093 & & \\
\cline { 2 - 7 } & Total & 4.934 & 46 & & & \\
\hline \multirow{2}{*}{$\begin{array}{c}\text { The knowledge levels of the } \\
\text { teachers related to } \\
\text { implementation }\end{array}$} & Between groups & 4.671 & 3 & 1.557 & 4.219 & .011 \\
\cline { 2 - 7 } & Within groups & 15.868 & 43 & .369 & & \\
\cline { 2 - 7 } & Total & 20.539 & 46 & & & \\
\hline \multirow{2}{*}{$\begin{array}{c}\text { The general knowledge level of } \\
\text { the teachers related to science } \\
\text { activities }\end{array}$} & Between groups & 1.085 & 3 & .362 & 3.415 & .026 \\
\cline { 2 - 7 } & Within groups & 4.553 & 43 & .106 & & \\
\hline & Total & 5.638 & 46 & & & .012 \\
\hline \multirow{2}{*}{$\begin{array}{c}\text { The behaviors the teachers present } \\
\text { during the implementation of } \\
\text { science activities }\end{array}$} & Between groups & 2.802 & 3 & .934 & 4.113 & \\
\cline { 2 - 7 } & Within groups & 9.765 & 43 & .227 & & \\
\cline { 2 - 7 } & Total & 12.567 & 46 & & & \\
\hline
\end{tabular}

Table 10. The ANOVA results of the preschool teachers related to years of seniority variable

\begin{tabular}{|c|c|c|c|c|c|c|}
\hline Sub-dimensions & & SS & df & MS & F & P \\
\hline \multirow{4}{*}{$\begin{array}{c}\text { The materials and methods the } \\
\text { teachers use }\end{array}$} & Between groups & 1.271 & 3 & .424 & 4.975 & .005 \\
\cline { 2 - 7 } & Within groups & 3.663 & 43 & .085 & & \\
\cline { 2 - 7 } & Total & 4.934 & 46 & & & \\
\hline \multirow{4}{*}{$\begin{array}{c}\text { The knowledge levels of the teachers } \\
\text { related to implementation }\end{array}$} & Between groups & 4.037 & 3 & 1.346 & 3.506 & .023 \\
\hline & Within groups & 16.503 & 43 & .384 & & \\
\hline & Total & 20.539 & 46 & & & \\
\hline \multirow{4}{*}{$\begin{array}{c}\text { The general knowledge level of the } \\
\text { teachers related to science activities }\end{array}$} & Between groups & 1.020 & 3 & .340 & 3.166 & \\
\cline { 2 - 7 } & Within groups & 4.618 & 43 & .107 & & \\
\hline & Total & 5.638 & 46 & & & \\
\hline \multirow{2}{*}{$\begin{array}{c}\text { The behaviors the teachers present } \\
\text { during the implementation of science } \\
\text { activities }\end{array}$} & Between groups & 1.996 & 3 & .665 & 2.706 & .045 \\
\hline & Within groups & 10.571 & 43 & .246 & & \\
\cline { 2 - 7 } & Total & 12.567 & 46 & & & \\
\hline
\end{tabular}


On analyzing the Table 10 , it can be seen that there is a significant difference between the scores of the preschool teachers from the sub-dimensions of TPSPAS and the years of seniority of the teachers $(p<0.05)$. Tukey test, one of the multi-comparison tests, was used to determine whichever age group this difference is in favor of. As a result of Tukey test, it was determined that for the materials and methods the teachers use, there is no difference between the adequacy scores of the preschool teachers with 6-10 years of seniority and the preschool teachers with 0-5 and 11-15 years of seniority, however, their average scores are higher than any other groups; there is a difference between the adequacy scores of the teachers with 16 years of seniority or more, and this difference is not in favor of the teachers with 16 years of seniority or more; for knowledge levels of the teachers related to implementation sub-dimension, there is no significant difference between the adequacy scores of the preschool teachers with 0-5 and 6-10 years of seniority, there is significant difference between the scores of the teachers with 11-15 years of seniority and the teachers with 16 years of seniority or more, and this difference is in favor of the teachers with 0-5 and 6-10 years of seniority; for knowledge level of the teachers related to science activities sub-dimension, there is no significant difference between the adequacy scores of the teachers with 6-10 years of seniority and the teachers with 0-5 years of seniority, however, there is significant difference between the scores of the teachers with 11-15 years of seniority and the teachers with 16 year of seniority or more, and this difference is in favor of the teachers with 0-5 and 6-10 years of seniority; for behaviors of the teachers presented during the implementation sub-dimension, there is no significant difference between the adequacy scores of the teachers with $0-5$ years of seniority and the teachers with 6-10 years of seniority, however, there is significant difference between the scores of the teachers with 11-15 years of seniority and the teachers with 16 years of seniority or more, and this difference is in favor of the teachers with $0-5$ and 6-10 years of seniority. ANOVA test was done in order to determine the difference in terms of educational status between the average values of the scores of the preschool teachers from the sub-dimension of TPSPAS. The results of the test are indicated in Table 11 below.

On analyzing the Table 11 , it is seen that there is no significant difference between the scores of the sub-dimensions of the materials and methods the teachers use, the knowledge level of the teachers related to implementation, the knowledge level of the teachers related to science activities and the educational status variable $(p>0.05)$. However, it is seen that there is significant difference between the scores of the teachers from the behaviors of the teachers presented during the implementation and educational status $(\mathrm{p}<0.05)$. Tukey test, one of the multi-comparison tests, was used to determine whichever age group this difference is in favor of. As a result of Tukey test, it was determined that the adequacy scores of the teachers with Bachelor's Degree are higher than those with Association Degree and open university degree, and there is no significant difference between the teachers with Associate Degree and the teachers with open university degree.

Table 11. ANOVA results of the preschool teachers related to educational status variable

\begin{tabular}{|c|c|c|c|c|c|c|}
\hline Sub-dimensions & & SS & df & MS & $\mathrm{F}$ & $\mathrm{P}$ \\
\hline \multirow{3}{*}{$\begin{array}{l}\text { The materials and methods the teachers } \\
\text { use }\end{array}$} & Between groups & .527 & 2 & .263 & 2.629 & .083 \\
\hline & Within groups & 4.407 & 44 & .100 & & \\
\hline & Total & 4.934 & 46 & & & \\
\hline \multirow{3}{*}{$\begin{array}{l}\text { The knowledge levels of the teachers } \\
\text { related to implementation }\end{array}$} & Between groups & .532 & 2 & .266 & .585 & .561 \\
\hline & Within groups & 20.007 & 44 & .455 & & \\
\hline & Total & 20.539 & 46 & & & \\
\hline \multirow{3}{*}{$\begin{array}{l}\text { The general knowledge level of the } \\
\text { teachers related to science activities }\end{array}$} & Between groups & .116 & 2 & .058 & .462 & .633 \\
\hline & Within groups & 5.522 & 44 & .126 & & \\
\hline & Total & 5.638 & 46 & & & \\
\hline \multirow{3}{*}{$\begin{array}{l}\text { The behaviors the teachers present } \\
\text { during the implementation of science } \\
\text { activities }\end{array}$} & Between groups & 2.167 & 2 & 1.084 & 4.585 & .016 \\
\hline & Within groups & 10.400 & 44 & .236 & & \\
\hline & Total & 12.567 & 46 & & & \\
\hline
\end{tabular}




\section{Results and Discussion}

In preschool in which the children start to gain the scientific process skills, science subjects should be given the due importance by the preschool teachers in order to gain the children these skills. In this direction, it was aimed to determine the views of the teachers related to science activities and the adequacy of the preschool teachers in science activities, and it was found that the $81 \%$ of the preschool teachers have just enrolled in the profession and $74 \%$ of them have Bachelor's Degree.

It was determined that the teachers act according to their instant thoughts without any criterions before implementing science activities in their classes. The fact that sample subjects related to science activities are not included in preschool curriculum causes the teachers to prepare the activities off their own bat. Also, it was seen that the preschool teachers use expression method and do activities while teaching science activities. The teachers should prepare activities in which the children can particularly be active while teaching science. As the students learn better by doing and experiencing, the students need to be provided such opportunities that they can gain experience. Although it is of higher importance for preschool children to gain scientific process skills by doing and experiencing, the fact that the preschool teachers use expression method and conduct the teaching via it causes the children not to gain enough experience. By choosing appropriate methods and techniques, to plan activities which make particularly the children active in science education would be beneficial for the children. According to the report prepared by International Study Centre (ISC), Turkey is among the countries which conduct the fewest experiments according to the data obtained from the teachers and the students (cited by Bagcı Kılıç [4]). The preschool teachers do not include science activities in their classes related to the subjects like seasons, living and inanimate, our organs, our world, plants and animals, colors, sound, light and magnetism (Ayvac1 et al. [3]; Demiriz and Ulutaş [8]; Gürdal et al. [13]).

In the interviews, the teachers expressed that science education in preschool is quite important. The teachers are in the opinion that the science activities should be included in preschool for the reasons like: as the children are researching and exploring period, for the children to know their environment, to improve the thinking capacity of the children, to provide the children to know the nature by using his/her sense of wonder and curiosity, for the children to develop a positive perspective towards the nature and animals, to improve their problem solving skills and to improve the creativity of the children. In spite of that, it is another result that the teachers spare less time for science activities, they do not have adequate knowledge and skills related to science subjects, they consider themselves inadequate in terms of science subjects. In another study, it is stated that the preschool science teachers consider themselves inadequate in science subjects and they want to take in-service trainings (Karaer and Kösterelioğlu [14]; Kildan and Pektaş [16]). This is the main problem encountered during the implementation of science activities. It is seen that the teachers encounter such problems as having difficulty in responding to the children's questions, explaining the topic in full detail, presenting the abstract subjects, catching the attention of the children and finding appropriate and understandable experiments for children. Similar results have been stated in other conducted studies (Karamustafaoğlu and Kandaz [15]).

According to the results obtained from TPSPAS in the study, there is a significant difference between the scores of the teachers from each sub-dimension of TPSPAS and the ages of the teachers. It was determined that this difference is not in favor of the teachers at the age of 36-40. It can be said that the fact that the teachers at the age of 36-40 graduated from the institutions in which old preschool curriculum was in force is effective on this result. It is because the science education was not adequately included in the former undergraduate curriculums.

It is seen that there is significant difference between the scores of the teachers from each sub-dimensions of TPSPAS and years of seniority of the teachers. It was determined that this difference is not in favor of the teachers with 16 years of seniority or more within the sub-dimensions of the scale. The fact that the teachers with 16 years of seniority conduct the old curriculums in their classes and do not follow the innovations is directly related with this result.

In the study, it was determined that there is no significant difference between scores of the teachers from the sub-dimensions of materials and methods the preschool teachers use, knowledge levels of the teachers related to implementation and knowledge levels of the teachers related to science activities and the educational status of the teachers, however, there is significant difference between the scores of the teachers from the sub-dimension of behaviors of the teachers presented during the implementation of science activities and the educational status of the teachers. As a result of the conducted analyses, it was concluded that this difference is in favor of the teachers with Bachelor's Degree. It can be said that the fact that the teachers with Bachelor's degree has a long education experience, gain the theoretical knowledge face to face and in a long time, and they have more opportunities to practice and implement is effective on this result.

Based on the results of this research the recommendations can be below;

1. In-service training should be given to the preschool teachers about science activities by administrators.

2. In in-service trainings, the teachers should be ensured to have awareness about the importance of science education especially in preschool, and the teachers should be informed about the science centers and they should also be informed how to use and develop these science centers.

3. Preschool teachers should benefit from different sources to gain more knowledge in science subjects. 
4. The teaching science course that the preschool teachers get during their undergraduate education should be carried out in way that they can understand the subject properly and pre-service teachers should be gained knowledge and experience with the practices about science activities that they can give to the preschool students.

5. After this study, researchers can conduct studies on adequacy of the preschool teachers related to science activities and the frequency of using different science activity.

\section{REFERENCES}

[1] Akçay, N. O. (2015). The investigation of preschool teacher candidates' self-efficacy beliefs in science teaching according to several variables. Route Educational and Social Science Journal, Vol. 2, No.4, 268-275.

[2] Aktaş, Y.A. (2002). Okul öncesi dönemde fen eğitiminin amaçları. Çocuk Gelişimi ve Eğitimi Dergisi, Vol.6, No.7, $1-6$.

[3] Ayvac1, H. Ş., Devecioğlu, Y. \& Yiğit, N. (2002). Okul öncesi ögretmenlerinin fen ve doğa etkinliklerindeki yeterliliklerinin belirlenmesi. V. Ulusal Fen ve Matematik Eğitimi Kongresi. Ortadoğu Teknik Üniversitesi, Ankara.

[4] Bagcı Kılıç, G. (2003). Üçüncü uluslararası matematik ve fen arastırmas1 (TIMSS): fen ögretimi, bilimsel arastırma ve bilimin dogas1. Ilkögretim Online, Vol.2, No.1, 42-51.

[5] Bal, S. (1993). Anaokullarında fen çalışmaları. 9. Ya-Pa Okulöncesi Egİtimi Ve YaygınlasTırılması Semineri. Istanbul: Ya-Pa yayınları.

[6] Balat, U. G. \& Önkol, L. (2010). Okul öncesi dönemde fen eğitimi öğretim yöntemleri. B. Akman, U.G. Balat ve T. Güler (Yay. Haz.). Okul öncesi dönemde fen eğitimi içinde (89-129). Ankara: Pegema Yayıncılık.

[7] Cho, H., Kim, J. \& Choi, D. H. (2003). Early childhood teachers' attitudes toward science teaching: a scale validation study. Educational Research Quarterly, Vol.27, No.2, 33-42.

[8] Demiriz, S. \& Ulutaş, İ. (2001). Okulöncesi eğitim kurumlarındaki fen ve doğa etkinlikleri ile ilgili uygulamaların belirlenmesi. Proceedings from IV. Congress of Science Education. Ankara: MEB Yayınları.

[9] Dikmen, B. (1994). Okul öncesi eğitimde doğa ve fen bilimleri etkinliklerinin yeri ve önemi: okulöncesi eğitimcileri için el kitabı. İstanbul: Ya-Pa Yayınları.

[10] Early, D.M., Iruka, I.U., Ritchie, S., Barbarin, O.A., Winn, D.C., Crawford, G.M., Frome, P.M., Clifford, R.M., Burchinal, M., Howes, C., Bryant, D.M. \& Pianta, R.C. (2010). How do pre-kindergarteners spend their time? Gender, ethnicity and income as predictors of experiences in pre-kindergarten classrooms. Early Childhood Education Quarterly, Vol.25, 177-93.

[11] Ginsburg, H. P. \& Golbeck, S. L. (2004). Thoughts on the future of research on mathematics and science learning and education Early Childhood Research Quarterly, Vol.19, No.1, $190-200$.

[12] Greenfield, D.B., Jirout, J., Dominguez, X., Greenberg, A., Maier, M. \& Fuccilo, J. (2009). Science in the preschool classroom: a programmatic research agenda to improve science readiness. Early Education and Development, Vol. 20, 238-64.

[13] Gürdal, A., Çağlar, A., Şahin, F., Ökçün, F. \& Macaroğlu, E. (1993). Okulöncesi dönemle ilgili fen faaliyetlerine örnekler. 9. Ya-Pa Okulöncesi Eğitimi ve Yaygınlaştırılması Semineri. İstanbul: Ya-Pa yayınları.

[14] Karaer, H. \& Kösterelioğlu, M. (2005). Amasya ve sinop illerinde çalısan okulöncesi ögretmenlerin fen kavramlarının ögretilmesinde kullandıkları yöntemlerin belirlenmesi, Kastamonu Egitim Dergisi, Vol.13, No.2, 447-454.

[15] Karamustafaoğlu, S. \& Kandaz, U. (2006). Okul öncesi egitimde fen etkinliklerinde kullanılan ögretim yöntemleri ve karsılasılan güçlükler. Gazi Egitim Fakültesi Dergisi, Vol.26, No.1, 65-81.

[16] Kıldan, O. \& Pektaș, M. (2009). Erken çocukluk döneminde fen ve doga ile ilgili konuların ögretilmesinde okulöncesi ögretmenlerinin görüslerinin belirlenmesi. Ahi Evran Üniversitesi Kırsehir Egitim Fakültesi Dergisi, Vol.10, No.1, 113-127.

[17] Kalley, M. \& Psillos D. (2001). Pre-school teachers' content knowledge in science: their understanding of elementary science concepts and of issues raised by children's questions. International Journal of Early Years Education, Vol.9, No.3, 165-179.

[18] Küçükturan, G. (2003). Okul öncesi fen öğretiminde bir teknik: analoji. Milli Eğitim Dergisi, Vol. 157, 9-15.

[19] Macaroğlu, A. E. (2004). Fen ve doğa etkinlikleri. İstanbul: Morpa Kültür Yayınları.

[20] McMillan, J. H. \& Schumacher, S. (2006). Research in education: evidence-based inquiry. (Sixth Edition). Boston, MA: Allyn and Bacon.

[21] Özbey, S. (2006). Okul öncesi eğitim kurumlarında görev yapan öğretmenlerin fen etkinliklerine ilişkin yeterliliklerinin belirlenmesi. (Yayınlanmamıș yüksek lisans tezi). Gazi Üniversitesi Eğitim Bilimleri Enstitüsü, Ankara.

[22] Patrick, H., Mantzicopoulos, P. \& Samarapungavan, A. (2009). Motivation for learning science in kindergarten: Is there a gender gap and does integrated inquiry and literacy instruction make a difference. Journal of Research in Science Teaching, Vol.46, No.2, 166- 191.

[23] Pell, A. \& Jarvis, T. (2003). Developing attitude to science education scales for use with primary teachers. International Journal of Science Education, Vol.25, 1273-1295.

[24] Sackes, M., Trundle, K.C., Bell, R.L. \& O'Connell, A.A. (2011). The influence of early science experience in kindergarten on children's immediate and later science achievement: Evidence from the early childhood longitudinal study. Journal of Research in Science Teaching, Vol.48, 217235 .

[25] Saçkes, M., Akman, B. \& Trundle, K. C. (2012). Okulöncesi ögretmenlerine yönelik fen egitimi dersi: lisans düzeyindeki ögretmen egitimi için bir model önerisi. Necatibey Egitim 
Fakültesi Elektronik Fen ve Matematik Egitimi Dergisi, Vol.6, No.2, 1-26.

[26] Saçkes, M. (2014). How often do early childhood teachers teach science concepts? Determinants of the frequency of science teaching in kindergarten. European Early Childhood
Education Research Journal, Vol.22, No.2, 169-184.

[27] Yasar, S. (1993). Okul öncesi egitim ögrencilerinde fene yönelik duyussal özelliklerin gelistirilmesi. 9. Ya-Pa Okul öncesi Egitimi ve Yaygınlastırılması Semineri. İstanbul: Ya-Pa yayınları. 